\title{
2'-Phosphate cyclase activity of RtcA: a potential rationale for the operon organization of RtcA with an RNA repair ligase RtcB in Escherichia coli and other bacterial taxa
}

\author{
USHATI DAS and STEWART SHUMAN ${ }^{1}$ \\ Molecular Biology Program, Sloan-Kettering Institute, New York, New York 10065, USA
}

\begin{abstract}
RNA terminal phosphate cyclase catalyzes the ATP-dependent conversion of a $3^{\prime}$-phosphate RNA end to a $2^{\prime}, 3^{\prime}$-cyclic phosphate

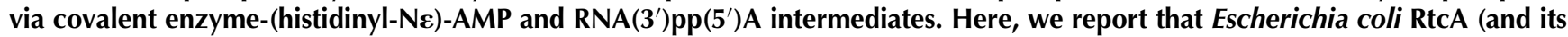
human homolog Rtc1) are capable of cyclizing a 2'-phosphate RNA end in high yield. The rate of 2'-phosphate cyclization by RtcA is five orders of magnitude slower than $3^{\prime}$-phosphate cyclization, notwithstanding that RtcA binds with similar affinity to RNA ${ }_{3}$ 'p and $\mathrm{RNA}_{2}$, $\mathrm{p}$ substrates. These findings expand the functional repertoire of RNA cyclase and suggest that phosphate geometry during adenylate transfer to RNA is a major factor in the kinetics of cyclization. RtcA is coregulated in an operon with an RNA ligase, RtcB, that splices RNA $5^{\prime}$-OH ends to either $3^{\prime}$-phosphate or $2^{\prime}, 3^{\prime}$-cyclic phosphate ends. Our results suggest that RtcA might serve an end healing function in an RNA repair pathway, by converting RNA $2^{\prime}$-phosphates, which cannot be spliced by RtcB, to $2^{\prime}, 3^{\prime}$-cyclic phosphates that can be sealed. The $r t c B A$ operon is controlled by the $\sigma^{54}$ coactivator RtcR encoded by an adjacent gene. This operon arrangement is conserved in diverse bacterial taxa, many of which have also incorporated the RNA-binding protein Ro (which is implicated in RNA quality control under stress conditions) as a coregulated component of the operon.
\end{abstract}

Keywords: 2',3'-cyclic phosphate ends; RNA repair

\section{INTRODUCTION}

RNA 2',3'-cyclic phosphate ends play important roles in RNA metabolism, especially as intermediates in RNA repair by polynucleotide ligases (Popow et al. 2012; Remus and Shuman 2013). Escherichia coli RtcB exemplifies a new clade of RNA ligases that join $2^{\prime}, 3^{\prime}$-cyclic phosphate and $5^{\prime}-\mathrm{OH}$ RNA ends to yield a $3^{\prime}-5^{\prime}$ phosphodiester splice junction (Englert et al. 2011; Popow et al. 2011; Tanaka and Shuman 2011; Tanaka et al. 2011a). RtcB is encoded in a two-gene operon in E. coli along with the RNA cyclase enzyme RtcA, which converts RNA $3^{\prime}$-phosphate ends to $2^{\prime}, 3^{\prime}$-cyclic phosphates (Fig. 1A; Genschik et al. 1998). The genetic organization of RtcA and RtcB prompted the suggestion that they provide the healing and sealing functions, respectively, in an RNA repair pathway (Tanaka and Shuman 2011). In this scenario, the healing refers to the restoration of ligatable $2^{\prime}, 3^{\prime}$-cyclic phosphate ends in the event that the inciting RNA damage directly generates RNA $3^{\prime}$-phosphates, or that the $2^{\prime}, 3^{\prime}$-cyclic phosphate products of RNA transesterification

\footnotetext{
${ }^{1}$ Corresponding author

E-mail s-shuman@ski.mskcc.org

Article published online ahead of print. Article and publication date are at http://www.rnajournal.org/cgi/doi/10.1261/rna.039917.113.
}

are further processed to a $3^{\prime}$-phosphate by a $2^{\prime}, 3^{\prime}$-cyclic phosphodiesterase. The fact that the $r t c B A$ operon in $E$. coli is regulated by the $\sigma^{54}$ coactivator RtcR (encoded by the $r t c R$ gene, located immediately upstream of $r t c B A$ and transcribed in the opposite orientation) suggested that the RNA repair functions are induced in response to cellular stress (Genschik et al. 1998), conceivably as a means to ameliorate the effects of bacterial ribotoxins that are turned on in stress situations.

The biochemical rationale for the two-component repair system was subsequently deflated by the discovery that $\mathrm{RtcB}$ is adept at joining $3^{\prime}$-phosphate $/ 5^{\prime}-\mathrm{OH}$ ends or $2^{\prime}, 3^{\prime}$-cyclic phosphate/ $5^{\prime}-\mathrm{OH}$ ends (Tanaka et al. $2011 \mathrm{~b}$; Chakravarty et al. 2012). We now appreciate that RtcB executes a four-step pathway of end joining that requires GTP as an energy source and $\mathrm{Mn}^{2+}$ as a cofactor (Tanaka et al. 2011b; Chakravarty et al. 2012; Chakravarty and Shuman 2012). RtcB first reacts with GTP to form a covalent RtcB-(histidinyl $\left.{ }^{337}-\mathrm{N}\right)$-GMP intermediate. It then hydrolyzes the RNA $2^{\prime}, 3^{\prime}$-cyclic phosphate end to a $3^{\prime}$-phosphate and transfers guanylate from His 337 to the RNA $3^{\prime}$-phosphate to form an RNA $\left(3^{\prime}\right) \mathrm{pp}\left(5^{\prime}\right) \mathrm{G}$ intermediate. Finally, RtcB catalyzes the attack of an RNA $5^{\prime}-\mathrm{OH}$ on the RNA $\left(3^{\prime}\right) \mathrm{pp}\left(5^{\prime}\right) \mathrm{G}$ end to form the splice junction and liberate GMP.

Given that RtcB has both cyclic phosphodiesterase and $3^{\prime}$ $\mathrm{PO}_{4} / 5^{\prime}-\mathrm{OH}$ ligase activities, the biochemical advantage to its 


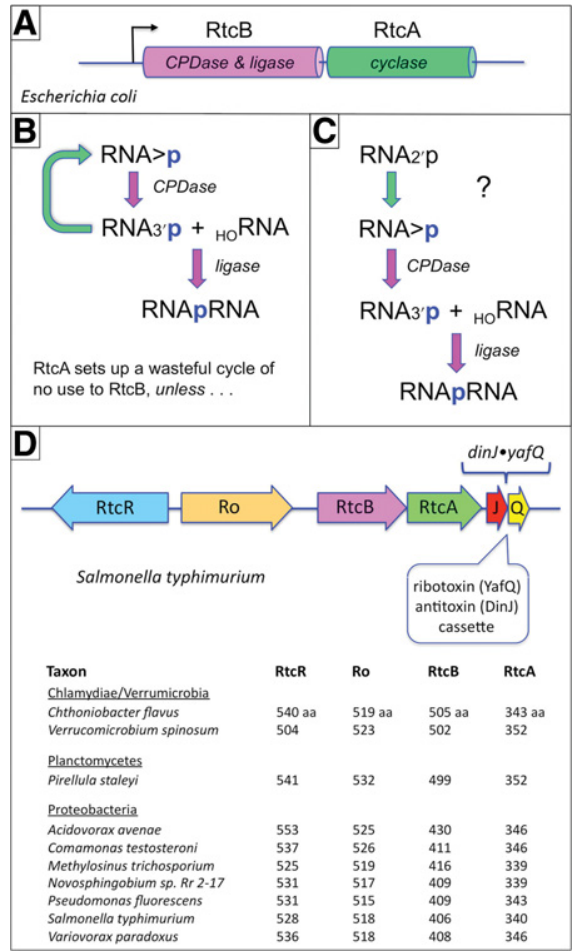

FIGURE 1. Bacterial $r t c B A$ operons and pathway options for RtcA in RNA repair. ( $A$ ) The RNA ligase RtcB is encoded in a two-gene operon in $E$. coli along with the RNA cyclase RtcA. $(B)$ The cyclic phosphodiesterase activity of RtcB hydrolyzes a $2^{\prime}, 3^{\prime}$-cyclic phosphate to a $3^{\prime}$-phosphate. The ligase activity of RtcB then joins the RNA $3^{\prime}$-phosphate to a $5^{\prime}-\mathrm{OH}$ RNA end to yield a $3^{\prime}-5^{\prime}$ phosphodiester splice junction. RtcA converts RNA $3^{\prime}$-phosphate ends to $2^{\prime}, 3^{\prime}$-cyclic phosphates, a reaction that appears wasteful from the perspective of RtcB. $(C)$ Were RtcA able to cyclize RNA 2'-phosphate ends, which are not substrates for sealing by RtcB, it might serve a useful function in an RNA repair pathway, as shown. (D) Schematic diagram of the Salmonella typhimurium operon in which $r t c B$ and $r t c A$ are preceded by a co-oriented ORF encoding Ro and followed by a co-oriented toxin-antitoxin cassette encoding the mRNA ribotoxin YafQ and its antitoxin DinJ. The operon is regulated by RtcR, a $\sigma^{54}$ coactivator encoded by an adjacent, oppositely oriented gene. Exemplary bacterial taxa that have an RtcR-regulated ro-RtcB-RtcA operon are listed; the sizes (aa) of the component proteins are shown.

coregulation with RtcA is not obvious. The combined action of the RtcA cyclase and RtcB cyclic phosphodiesterase seems to create a futile cycle (Fig. 1B) that is energetically wasteful, insofar as cyclization consumes ATP. RtcA generates $2^{\prime}, 3^{\prime}$-cyclic phosphate ends via three steps: reaction with ATP to form a covalent RtcA-(histidinyl ${ }^{309}-\mathrm{N} \varepsilon$ )-AMP intermediate; transfer of adenylate to the RNA $3^{\prime}$-phosphate to form an RNA $\left(3^{\prime}\right)$ $\mathrm{pp}\left(5^{\prime}\right) \mathrm{A}$ intermediate; and attack of the vicinal $\mathrm{O} 2^{\prime}$ on the $3^{\prime}-$ phosphorus to form a $2^{\prime}, 3^{\prime}$-cyclic phosphate product and release AMP (Filipowicz et al. 1985; Genschik et al. 1998; Billy et al. 1999; Tanaka et al. 2010). Whereas RtcB and RtcA are structurally unrelated proteins with no similarities in their active sites (Tanaka et al. 2010; Chakravarty et al. 2011; Englert et al. 2012), they do share two mechanistic features: (1) reliance on a histidine nucleophile for covalent nucleo- tidyl transfer; and (2) synthesis of an RNA 3'-phosphodiester via a covalently activated $\mathrm{RNA}\left(3^{\prime}\right) \mathrm{pp}\left(5^{\prime}\right) \mathrm{N}$ intermediate.

The functions of RNA cyclase in cellular RNA metabolism are unknown, and it remains unclear whether cyclization of $3^{\prime}$-phosphates is the only biochemical pathway in which RtcA enzymes participate. For example, E. coli RtcA catalyzes adenylylation of $5^{\prime}$-phosphate ends of DNA or RNA strands to form $\mathrm{A}\left(5^{\prime}\right) \mathrm{pp}\left(5^{\prime}\right) \mathrm{DNA}$ and $\mathrm{A}\left(5^{\prime}\right) \mathrm{pp}\left(5^{\prime}\right) \mathrm{RNA}$ products (Chakravarty and Shuman 2011). Biological scenarios in which the $5^{\prime}$ adenylyltransferase activity of RtcA might play a role include: (1) adenylylation of DNA or RNA $5^{\prime}$ ends as a means of protecting them against exonucleolytic decay, analogous to the function of the eukaryal mRNA cap; (2) installing an inverted $5^{\prime}$ adenylate as a "mark" that targets RNA or DNA molecules for downstream events, e.g., localization, translation, recombination, etc.; or (3) the generation of AppDNA or AppRNA ends that serve as substrates for ligation of AppDNA/RNA to 3'-OH termini by a separate repair enzyme (Chakravarty and Shuman 2011).

With respect to the connection of RtcA and RtcB, we considered the prospect that RNA cyclase might be capable of acting on RNA 2'-phosphate ends, which are not substrates for sealing by RtcB (Tanaka et al. 2011b). In this scenario, RtcA would serve an end healing function in an RNA repair pathway, by converting RNA $2^{\prime}$-phosphates to $2^{\prime}, 3^{\prime}$-cyclic phosphates that can then be sealed by RtcB (Fig. 1C). The goal of the present study was to determine whether RtcA can cyclize a $2^{\prime}$-phosphate end.

\section{RESULTS AND DISCUSSION}

\section{RtcA cyclizes an RNA 2'-phosphate end}

In the experiment in Figure 2A, RtcA was reacted with otherwise identical 20-mer RNAs with $3^{\prime}$-phosphate or 2'-phosphate ends and a single radiolabel between the $3^{\prime}$-terminal and penultimate nucleosides (Fig. 2A). The $\mathrm{RNA}_{3^{\prime}} \mathrm{p}$ and $\mathrm{RNA}_{2} \mathrm{p}$ substrates $(20 \mathrm{nM})$ were incubated for $30 \mathrm{~min}$ at $37^{\circ} \mathrm{C}$ with $10 \mathrm{mM} \mathrm{MgCl} 2,100 \mu \mathrm{M}$ ATP, and either $1.5 \mu \mathrm{M}$ wild-type RtcA or the active site mutant H309A. To enable resolution of the reactants and products with different $3^{\prime}$ ends, the RNAs were digested with RNase T1 prior to analysis by denaturing PAGE (Fig. 2A). RNase T1 incised the substrates $3^{\prime}$ of the most distal guanosine to yield the ${ }^{32} \mathrm{P}$-labeled tetranucleotides ${ }_{\mathrm{HO}} \mathrm{CUUpC}_{3^{\prime}} \mathrm{p}$ or ${ }_{\mathrm{HO}} \mathrm{CUUpC}_{2^{\prime}} \mathrm{p}$, which migrated identically during PAGE (Fig. 2A, lanes -). In the presence of RtcA, the $\mathrm{RNA}_{3^{\prime}} \mathrm{p}$ and $\mathrm{RNA}_{2^{\prime}} \mathrm{p}$ substrates were both converted into an RNA $>$ p product that, after incision by RNase T1, yielded a $2^{\prime}, 3^{\prime}$-cyclic phosphate-terminated tetranucleotide, ${ }_{\mathrm{HO}} \mathrm{CUUpC}>\mathrm{p}$, that migrated slower during PAGE than the phosphomonoester-terminated tetranucleotides (Fig. 2A). RtcA effected near-quantitative cyclization of the $2^{\prime}$-phosphate and $3^{\prime}$-phosphate ends. In contrast, the RtcA H309A mutant, which is unable to form the covalent RtcA-AMP intermediate, was unreactive with either $\mathrm{RNA}_{3^{\prime}} \mathrm{p}$ 


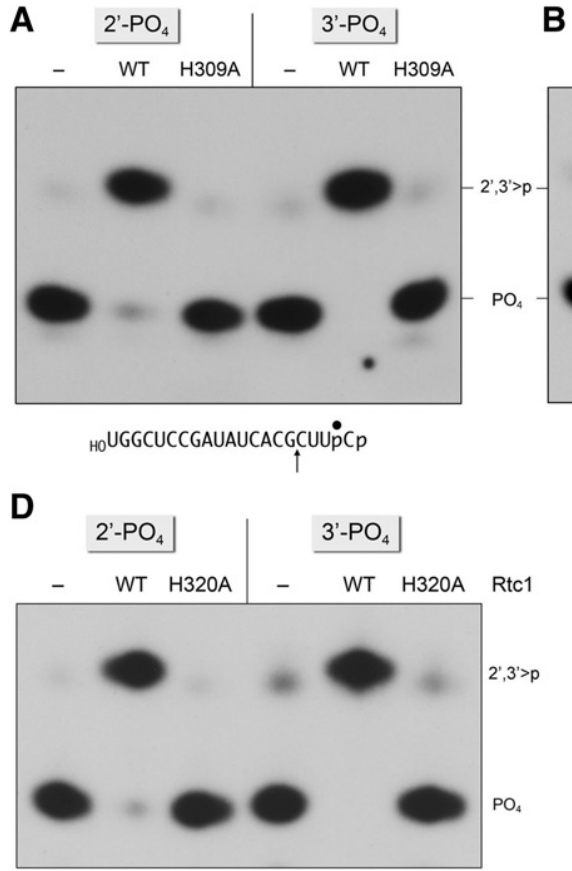

B

$\begin{array}{lllllll}0 & 5 & 1 & 2 & 5 & 7.5 & 15\end{array}$

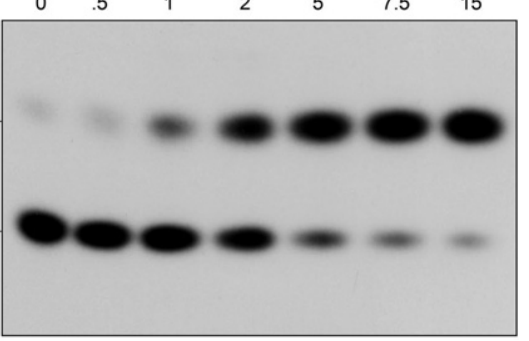

C

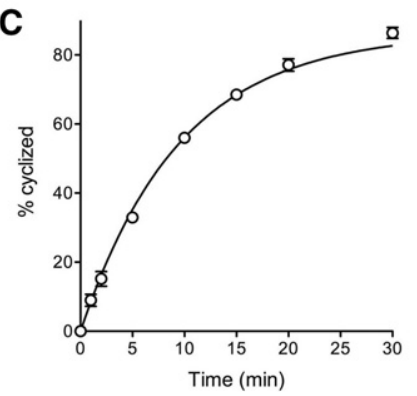

FIGURE 2. RtcA cyclizes a $2^{\prime}$-phosphate end. (A) Reaction mixtures $(10 \mu \mathrm{L})$ containing $50 \mathrm{mM}$ Tris- $\mathrm{HCl}$ (pH 7.4), $10 \mathrm{mM} \mathrm{MgCl}_{2}, 2$ mM DTT, $100 \mu \mathrm{M}$ ATP, $20 \mathrm{nM} 20$-mer $\mathrm{RNA}_{2^{\prime}} \mathrm{p}\left(2^{\prime}-\mathrm{PO}_{4}\right)$ or $\mathrm{RNA}_{3^{\prime}} \mathrm{p}\left(3^{\prime}-\mathrm{PO}_{4}\right)$ substrate (depicted at bottom with the ${ }^{32} \mathrm{P}$ label denoted by $\bullet$ ), and either no enzyme (lanes -) or $1.5 \mu \mathrm{M}$ wild-type E. coli RtcA or mutant RtcA-H309A were incubated for $30 \mathrm{~min}$ at $37^{\circ} \mathrm{C}$. The reactions were quenched with EDTA. The products were digested with RNase T1 and then analyzed by urea-PAGE. An autoradiogram of the gel is shown. The terminal phosphorylation states of the ${ }^{32} \mathrm{P}$-labeled RNase $\mathrm{T} 1$ fragments are indicated at right. (B) Reaction mixtures $(10 \mu \mathrm{L})$ containing $50 \mathrm{mM}$ Tris- $\mathrm{HCl}(\mathrm{pH} 7.4), 10 \mathrm{mM} \mathrm{MgCl}, 2 \mathrm{mM}$ DTT, $100 \mu \mathrm{M}$ ATP, $20 \mathrm{nM}(0.2 \mathrm{pmol}) 20-\mathrm{mer}^{2} \mathrm{RNA}_{2^{\prime}} \mathrm{p}\left(2^{\prime}-\mathrm{PO}_{4}\right)$ substrate, and RtcA as specified were incubated for 30 min at $37^{\circ} \mathrm{C}$. $(C)$ A reaction mixture $(70 \mu \mathrm{L})$ containing $50 \mathrm{mM}$ Tris- $\mathrm{HCl}(\mathrm{pH} 7.4), 10 \mathrm{mM}$ $\mathrm{MgCl}_{2}, 2 \mathrm{mM}$ DTT, $100 \mu \mathrm{M}$ ATP, $20 \mathrm{nM} 20$-mer RNA $2^{\prime} \mathrm{p}\left(2^{\prime}-\mathrm{PO}_{4}\right)$, and $1.5 \mu \mathrm{M}$ RtcA was incubated at $37^{\circ} \mathrm{C}$. Aliquots $(10 \mu \mathrm{L})$ were withdrawn at the times specified and quenched immediately with SDS and EDTA. After phenol-chloroform extraction, the mixtures were digested with RNase $\mathrm{T} 1$ and analyzed by PAGE. The extent of cyclization is plotted as a function of reaction time. Each datum is the average of three separate experiments \pm SEM. A nonlinear regression curve fit of the data to a one-phase association (executed in Prism) is shown. The apparent rate constant for $2^{\prime}$ phosphate cyclization was $0.1 \pm 0.003 \mathrm{~min}^{-1}$. (D) RNA $2^{\prime}$-phosphate cyclase activity of human Rtcl. Reaction mixtures $(10 \mu \mathrm{L})$ containing $50 \mathrm{mM}$ Tris- $\mathrm{HCl}(\mathrm{pH} 7.4), 10 \mathrm{mM} \mathrm{MgCl}, 2 \mathrm{mM}$ DTT, $100 \mu \mathrm{M}$ ATP, $20 \mathrm{nM} 20$-mer $\mathrm{RNA}_{2^{\prime}} \mathrm{p}\left(2^{\prime}-\mathrm{PO}_{4}\right)$ or $\mathrm{RNA}_{3^{\prime}} \mathrm{p}\left(3^{\prime}-\mathrm{PO}_{4}\right)$ substrate, and either no enzyme (lanes -) or $1.5 \mu \mathrm{M}$ wild-type human Rtcl or mutant Rtc1-H320A were incubated for $30 \mathrm{~min}$ at $37^{\circ} \mathrm{C}$. The reactions were quenched with EDTA. The products were digested with RNase T1 and then analyzed by urea-PAGE. An autoradiogram of the gel is shown.

or $\mathrm{RNA}_{2^{\prime}} \mathrm{p}$. These results establish that $E$. coli RtcA can indeed cyclize an RNA 2'-phosphate end in high yield.

We performed similar experiments with human RNA cyclase Rtc1 (Genschik et al. 1997; Tanaka and Shuman 2009) and found that it, too, converted the $\mathrm{RNA}_{3^{\prime}} \mathrm{p}$ and $\mathrm{RNA}_{2}$, $\mathrm{p}$ substrates to RNA $>$ p products in a reaction that depended on the His320 nucleophile that forms the covalent Rtc1-AMP intermediate (Fig. 2D).

\section{Kinetics of 2'-phosphate and 3'-phosphate cyclization by RtcA}

The extent of cyclization of the $\mathrm{RNA}_{2^{\prime}} \mathrm{p}$ substrate during a 30 -min reaction at $37^{\circ} \mathrm{C}$ was proportional to the concentra- tion of input RtcA up to $0.5 \mu \mathrm{M}$ RtcA; the reaction was effectively complete at 0.75 and $1.5 \mu \mathrm{M}$ RtcA (Fig. 2B). The kinetics of 2'-phosphate cyclization by 1.5 $\mu \mathrm{M}$ RtcA are shown in Figure $2 \mathrm{C}$. The data fit well to a one-phase association with an apparent rate constant of $0.1 \pm$ $0.003 \mathrm{~min}^{-1}$.

The rate of 3 '-phosphate cyclization by RtcA under conditions of enzyme excess was too fast to measure manually. Therefore, we employed a rapid mix-quench apparatus to access the reaction on a millisecond time scale. Equal volumes of enzyme and substrate solutions were mixed at $22^{\circ} \mathrm{C}$ to achieve final concentrations of $20 \mathrm{nM} \mathrm{RNA}_{3^{\prime}} \mathrm{p}$ and $200 \mathrm{nM}$ RtcA. ATP and $\mathrm{Mg}^{2+}$ were omitted in order to ensure that cyclic product formation reflected a single-turnover reaction by preformed RtcA-AMP. We determined by enzyme titration in the absence of ATP that preformed RtcA-AMP comprised $25 \%$ of the RtcA preparation. Prior studies had established that, whereas RtcA requires a divalent cation to form the RtcA-AMP intermediate, preformed RtcA-AMP does not need a metal cofactor to execute $3^{\prime}$-phosphate cyclization (Chakravarty et al. 2011). The rapid mix reactions were quenched with SDS and EDTA. The SDS was removed by extraction with phenol-chloroform prior to treating the mixtures with RNase $\mathrm{T} 1$ and analyzing the products by denaturing PAGE. The kinetic profile showed that the RNA $>$ p product accumulated steadily up to $25 \mathrm{msec}$ and plateaued at $100 \mathrm{msec}$ with an endpoint of $93 \% \mathrm{cy}$ clization (Fig. 3A). Nonlinear regression fitting of the data to a one-phase association yielded an apparent rate constant of $163 \pm 14 \mathrm{sec}^{-1}$.

\section{Binding of RtcA to $2^{\prime}$-phosphate and $3^{\prime}$-phosphate terminated RNAs}

To interrogate the role of terminal phosphate position in RtcA binding to RNA, we exploited an electrophoretic mobility shift assay format that had been used previously to demonstrate that: (1) human RNA cyclase Rtc1 forms a discrete stable complex with 3 '-phosphate-terminated RNA and (2) $\mathrm{RNA}_{3}$ ' $\mathrm{p}$ binding by Rtc1 is independent of enzyme adenylylation, insofar as the H320A mutant bound RNA as well as wild-type Rtc1 (Tanaka and Shuman 2009). Here, otherwise identical 20-mer RNAs (20 nM) with 3'-phosphate, 

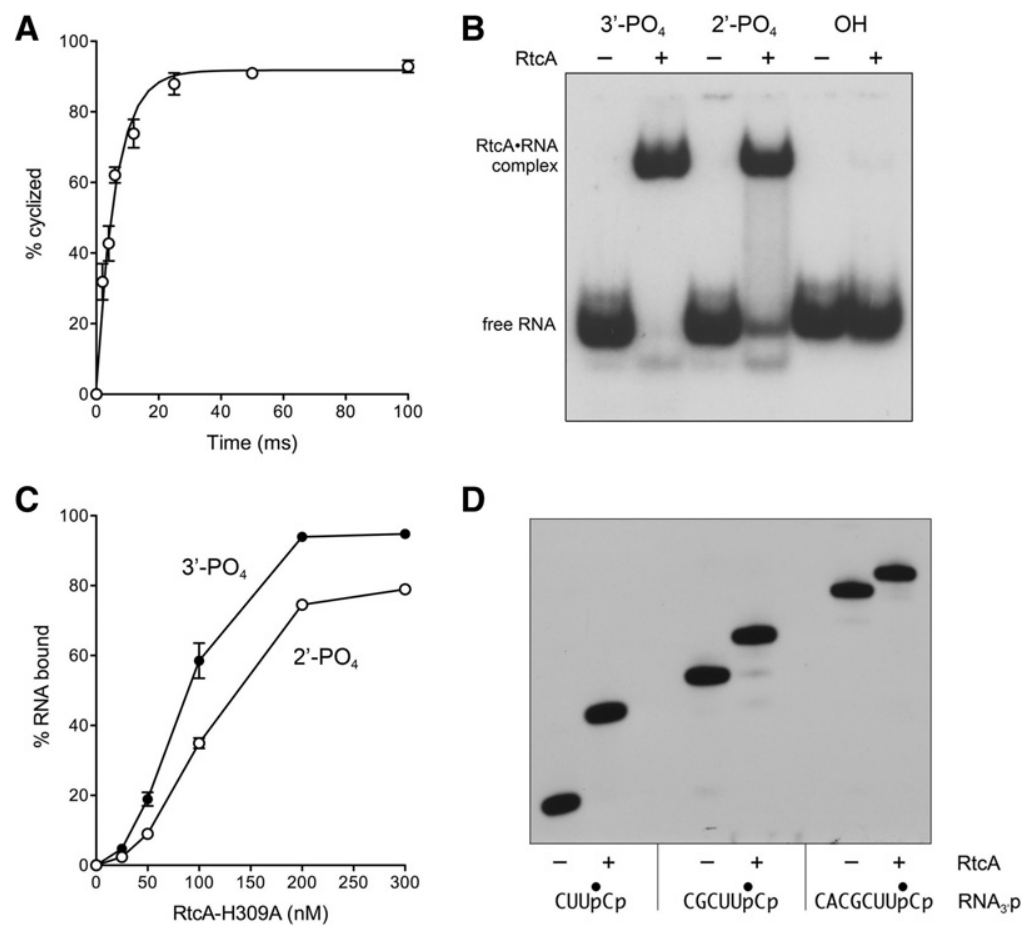

FIGURE 3. Kinetics of $3^{\prime}$-phosphate cyclization, binding of RtcA to $3^{\prime}$-phosphate and $2^{\prime}$-phosphate RNAs, and minimized RNA substrate for cyclization. $(A)$ Kinetics. Reaction mixtures containing 50 mM Tris-HCl (pH 7.4), 2 mM DTT, $20 \mathrm{nM}^{32}$ P-labeled 20-mer RNA $3^{\prime}$, and $200 \mathrm{nM}$ RtcA were incubated at $22^{\circ} \mathrm{C}$. The extent of $3^{\prime}$-phosphate cyclization is plotted as a function of reaction time. Each datum is the average of three separate experiments \pm SEM. A nonlinear regression curve fit of the data to a one-phase association (executed in Prism) is shown. (B) RNA binding. Reaction mixtures containing $50 \mathrm{mM}$ Tris- $\mathrm{HCl}$ ( $\mathrm{pH}$ 7.4), $1 \mathrm{mM}$ DTT, $20 \mathrm{nM}^{32}$ P-labeled 20mer $\mathrm{RNA}_{3^{\prime}} \mathrm{p}\left(3^{\prime}-\mathrm{PO}_{4}\right)$ or $\mathrm{RNA}_{2^{\prime}} \mathrm{p}\left(2^{\prime}-\mathrm{PO}_{4}\right)$ or $\mathrm{RNA}_{\mathrm{OH}}(\mathrm{OH})$ substrate, and either no enzyme or $300 \mathrm{nM}$ of RtcA-H309A (where indicated by + ) were incubated for $20 \mathrm{~min}$ at $37^{\circ} \mathrm{C}$. The mixtures were placed on ice, adjusted to $10 \%$ glycerol and $0.04 \%$ Triton-X100, and then analyzed by native PAGE. The ${ }^{32} \mathrm{P}$-labeled free RNAs and RtcA $\cdot$ RNA complexes were visualized by autoradiography. (C) Reaction mixtures containing $50 \mathrm{mM}$ Tris- $\mathrm{HCl}$ (pH 7.4), $1 \mathrm{mM}$ DTT, $20 \mathrm{nM}$ of a 20-mer $\mathrm{RNA}_{3^{\prime}} \mathrm{p}\left(3^{\prime}-\mathrm{PO}_{4}\right)$ or $\mathrm{RNA}_{2^{\prime}} \mathrm{p}\left(2^{\prime}-\mathrm{PO}_{4}\right)$ substrate, and RtcA-H309A as indicated were incubated for $20 \mathrm{~min}$ at $37^{\circ} \mathrm{C}$. The extents of RtcA $\cdot$ RNA complex formation are plotted as a function of input RtcA. Each datum is the average of three independent RtcA titration experiments ( \pm SEM). (D) Minimized RNA substrate. Reaction mixtures $(10 \mu \mathrm{L})$ containing $50 \mathrm{mM}$ Tris- $\mathrm{HCl}$ (pH 7.4), $10 \mathrm{mM} \mathrm{MgCl}, 2 \mathrm{mM}$ DTT, $100 \mu \mathrm{M}$ ATP, $20 \mathrm{nM}$ of 4-mer, 6-mer, or 8-mer $\mathrm{RNA}_{3^{\prime}} \mathrm{P}$ substrates labeled with ${ }^{32} \mathrm{P}$ at the penultimate phosphate, and either no enzyme (-) or $200 \mathrm{nM}$ RtcA (+) were incubated for $30 \mathrm{~min}$ at $37^{\circ} \mathrm{C}$. The reactions were quenched by adding an equal volume of $90 \%$ formamide and $50 \mathrm{mM}$ EDTA, and then analyzed by urea-PAGE. An autoradiogram of the gel is shown. The nucleotide sequences of the $\mathrm{RNA}_{3^{\prime}} \mathrm{p}$ strands are shown below the autoradiogram; the position of the ${ }^{32} \mathrm{P}$-label is denoted by $\bullet$.

$2^{\prime}$-phosphate, or $2^{\prime}, 3^{\prime}$-hydroxyl ends and a single radiolabel between the $3^{\prime}$-terminal and penultimate nucleosides were incubated with $300 \mathrm{nM}$ RtcA-H309A in the absence of ATP or divalent cation. The mixtures were then analyzed by electrophoresis through a native $10 \%$ polyacrylamide gel. RtcA formed a discrete protein $\cdot R N A$ complex with the $2^{\prime}$-phosphate and 3'-phosphate RNAs that was well resolved from the free RNA (Fig. 3B). In contrast, there was no detectable binding of RtcA to the $\mathrm{RNA}_{\mathrm{OH}}$ ligand (Fig. 3B), thereby attesting to a stringent requirement for a terminal phosphate for RtcA to engage its substrate.

The dependence of RNAp binding as a function of RtcA concentration is shown in Figure 3C. Taking the slope of the binding curve in the linear range of RtcA dependence ( 25 to $200 \mathrm{nM}$ ) as a metric of RNA binding affinity (calculated by linear regression in Prism), we surmise that RtcA binds 2'-phosphate RNA $80 \%$ as well as it binds $3^{\prime}$-phosphate RNA.

\section{Minimized substrate for cyclization}

Prior studies had shown that, whereas 12-mer, 11-mer, or 10-mer $\mathrm{RNA}_{3^{\prime}} \mathrm{p}$ substrates could be cyclized quantitatively by RtcA and Rtcl, these enzymes were unable to cyclize mononucleotide $5^{\prime}, 3^{\prime}$ bisphosphate $(\mathrm{pNp})$ or dinucleotide- $3^{\prime}$ phosphate $(\mathrm{NpNp})$ substrates (Reinberg et al. 1985; Genschik et al. 1997, 1998; Tanaka and Shuman 2009; Tanaka et al. 2010). The minimal effective substrate for human RNA cyclase is a trinucleotide-3'-phosphate (Reinberg et al. 1985). Here, we found that E. coli RtcA could quantitatively cyclize 8-mer, 6-mer, and 4-mer $\mathrm{RNA}_{3^{\prime}} \mathrm{p}$ substrates (Fig. 3D).

\section{Cyclization of DNA with a single 3'-terminal ribonucleotide}

Although DNA 3'-phosphate ends obviously cannot be cyclized, Filipowicz et al. (1985) showed that prolonged incubation of a $\mathrm{DNA}_{3}$ 'p substrate with excess human RNA cyclase generated low amounts of $\mathrm{DNA}_{3^{\prime}} \mathrm{ppA}$. The observation that cold $\mathrm{DNA}_{3^{\prime}} \mathrm{p}$ was 500 - to 1000 -fold less effective than an otherwise identical cold $\mathrm{RNA}_{3^{\prime}} \mathrm{p}$ in inhibiting cyclization of a radiolabeled $\mathrm{RNA}_{3}$, $\mathrm{p}$ substrate by human or E. coli RNA cyclases (Genschik et al. 1997, 1998) signified that the feeble use of $\mathrm{DNA}_{3^{\prime}} \mathrm{p}$ as an acceptor for adenylate transfer reflected, in large part, its weak interaction with the cyclase enzyme. Here, we queried the basis for discrimination of RNA vs. DNA by testing whether RtcA could cyclize an 18-mer substrate, D17R $1_{3^{\prime}} \mathrm{P}$, consisting of 17 deoxynucleotides and a single $3^{\prime}$-terminal ribonucleotide, with a ${ }^{32} \mathrm{P}$-label at the $3^{\prime}$-phosphate. The substrate was prepared by templated enzymatic ligation of a cold $\mathrm{D} 17 \mathrm{R} 1_{\mathrm{OH}}$ strand, $5^{\prime}$-d(CATATCCGTGTCGCCCT)(rC), to a $5^{\prime}{ }^{32}$ P-labeled 10-mer DNA strand, $5^{\prime}$-pATTCCGATAG, followed by digestion of the isolated D17R1pD10 strand with RNase A to yield $\mathrm{D} 17 \mathrm{R} 1_{3^{\prime}} \mathrm{p}$. The gel-purified $\mathrm{D} 17 \mathrm{R} 1_{3^{\prime}} \mathrm{p}$ oligonucleotide (shown in Fig. 4A) was reacted with RtcA, and the products were analyzed by PAGE, either directly or after treatment 


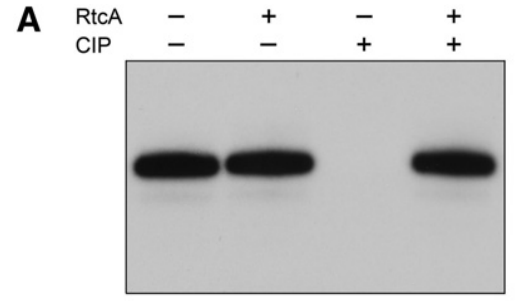

CATATCCGTGTCGCCCTC:

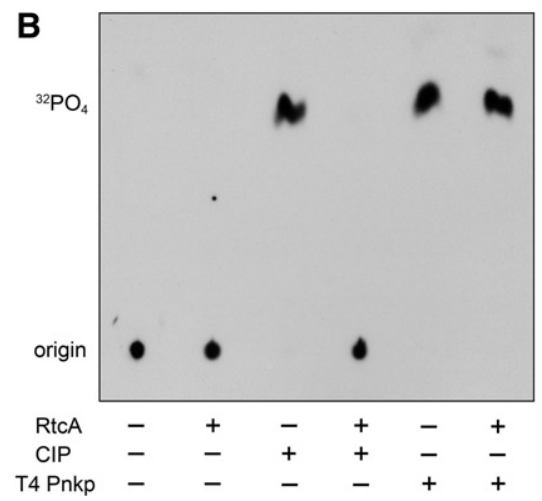

FIGURE 4. Cyclization of DNA with a single $3^{\prime}$-terminal ribonucleotide. (A) Reaction mixtures $(10 \mu \mathrm{L})$ containing $50 \mathrm{mM}$ Tris- $\mathrm{HCl}(\mathrm{pH}$ 7.4), $10 \mathrm{mM} \mathrm{MgCl}_{2}, 2 \mathrm{mM}$ DTT, $100 \mu \mathrm{M}$ ATP, $20 \mathrm{nM}$ D17R1 $1_{3^{\prime}} \mathrm{p}$ substrate (depicted at bottom with the ${ }^{32} \mathrm{P}$ label denoted by $\bullet$ and the terminal ribonucleotide highlighted in gray), and either $400 \mathrm{nM}$ RtcA (where indicated by + ) or no added enzyme (-) were incubated for $30 \mathrm{~min}$ at $37^{\circ} \mathrm{C}$. The mixtures were then treated with calf intestine phosphatase $\left(\mathrm{CIP}\right.$, where indicated by + ) for $30 \mathrm{~min}$ at $37^{\circ} \mathrm{C}$. The CIP-treated and mock-treated samples were mixed with an equal volume of formamide and EDTA, and then analyzed by electrophoresis through a $40-\mathrm{cm} 20 \%$ polyacrylamide gel containing $7 \mathrm{M}$ urea in $45 \mathrm{mM}$ Tris borate, $1.2 \mathrm{mM}$ EDTA. An autoradiogram of the gel is shown. $(B)$ Reaction mixtures (10 $\mu \mathrm{L}$ ) containing $50 \mathrm{mM}$ Tris- $\mathrm{HCl}(\mathrm{pH} 7.4), 10 \mathrm{mM} \mathrm{MgCl}_{2}, 2 \mathrm{mM}$ DTT, $100 \mu \mathrm{M}$ ATP, $0.2 \mu \mathrm{M}$ D17R1 $1_{3^{\prime}} \mathrm{p}$ substrate, and either $4 \mu \mathrm{M}$ RtcA (where indicated by + ) or no added enzyme $(-)$ were incubated for $30 \mathrm{~min}$ at $37^{\circ} \mathrm{C}$. The mixtures were then treated with either CIP or T4 polynucleotide kinase-phosphatase (Pnkp) for $30 \mathrm{~min}$ at $37^{\circ} \mathrm{C}$. The treated and mock-treated samples were adjusted to $1 \mathrm{M}$ formic acid and analyzed by PEI-cellulose TLC with $0.75 \mathrm{M} \mathrm{LiCl}$ as the mobile phase. An autoradiograph of the chromatogram is shown. The origin and the species corresponding to ${ }^{32} \mathrm{PO}_{4}$ are indicated on the left.

with calf intestine alkaline phosphatase (CIP). The radiolabel in the input $\mathrm{D} 17 \mathrm{R} 1_{3^{\prime}} \mathrm{p}$ strand was removed completely by CIP. The reaction with RtcA rendered the labeled strand resistant to CIP (Fig. 4A). The lack of a change in electrophoretic mobility of the oligonucleotide after reaction with RtcA is consistent with the CIP-resistant species being the cyclized product D17R1 $>$ p, rather than D17R1ppA, which would migrate above the substrate during PAGE. Analysis of the reaction products by PEI-cellulose TLC showed that, whereas CIP treatment of the input D17R $1_{3^{\prime}}$ p oligonucleotide (which remained at the chromatographic origin) quantitatively liberated ${ }^{32} \mathrm{P}$ inorganic phosphate, prior reaction with RtcA rendered the product resistant to hydrolysis by CIP (Fig. 4B). However, the ${ }^{32} \mathrm{P}$-label in both the substrate and the RtcA reaction product was sensitive to hydrolysis by T4 polynucleo- tide kinase-phosphatase (Pnkp) (Fig. 4B), which releases $P_{i}$ from either $3^{\prime}$-phosphate or $2^{\prime}, 3^{\prime}$-cyclic phosphate termini (Das and Shuman 2013) but would not be able to liberate $\mathrm{P}_{\mathrm{i}}$ from D17R1ppA. We surmise that a single terminal ribonucleoside suffices for productive cyclization by RtcA.

\section{Mechanistic implications for RNA cyclase}

The experiments presented above establish that RtcA can cyclize an RNA 2'-phosphate with high efficiency, albeit slowly compared to its reaction at an RNA 3'-phosphate end, which is faster by a factor of $10^{5}$. This huge rate disparity contrasts with the rather modest effect of terminal phosphate position on the binding of RtcA to its RNA substrate. We infer that RtcA discriminates kinetically between $3^{\prime}$ - and 2'-phosphates at the level of adenylate transfer chemistry from RtcA-AMP to RNAp to form the RNAppA intermediate and/or the intramolecular reaction of RNAppA to form RNA $>p$ and release AMP. The RNA adenylylation step of the RtcA pathway entails the attack of a terminal phosphate oxygen on the phosphorus atom of RtcA-(His309-Ne)-AMP to generate RNAppA and expel His309. The RNA adenylylation reaction is metal-independent and is thought to be catalyzed by essential basic residues that coordinate the RNA terminal phosphate (Tanaka and Shuman 2009; Chakravarty et al. 2011). A critical requirement for catalysis of RNA adenylylation is that the phosphate oxygen nucleophile be positioned apical to the histidine-Ne leaving group. We speculate that the extreme rate disparity between $3^{\prime}$ - and $2^{\prime}$-phosphate cyclization reflects an unfavorable alignment of the $2^{\prime}$-phosphate with respect to the His309-AMP adduct. Phosphate position may also influence the subsequent cyclization step, in which the vicinal ribose hydroxyl is activated for attack on RNAppA, e.g., whereby the geometry of the ribose $\mathrm{O}^{\prime}$ with respect to the AMP leaving group of $\mathrm{RNA}_{2^{\prime}} \mathrm{PpA}$ is not auspicious for an in-line displacement. We favor the idea that a $2^{\prime}$-phosphate drastically slows the rate of the RNA adenylylation step, because we did not detect the accumulation of an adenylylated RNA species (migrating above the RNA $>$ p product during PAGE) during reaction of a molar excess of RtcA with the $\mathrm{RNA}_{2}$ p substrate (data not shown). If the intramolecular cyclization of $\mathrm{RNA}_{2}$ 'ppA was rate-limiting, we would expect to see significant accumulation of an adenylated RNA intermediate. Even during the very rapid single-turnover reaction of RtcA with the $\mathrm{RNA}_{3}$ p substrate, we observed only very scant amounts of a putative RNAppA species, signifying that intramolecular cyclization is faster than RNAp adenylylation, whether at a $2^{\prime}$-phosphate or a $3^{\prime}$-phosphate end. It is worth noting that the rate of $2^{\prime}$-phosphate cyclization by $\operatorname{RtcA}\left(0.1 \mathrm{~min}^{-1}\right)$ is similar to the rate of the $5^{\prime}$-phosphate adenylylation reaction $\left(0.18 \mathrm{~min}^{-1}\right)$ (Chakravarty and Shuman 2011). A full accounting of the terminal phosphate position effect on polynucleotide adenylylation and cyclization will hinge on obtaining new crystal structures of RtcA in complexes with $3^{\prime}$-phosphate, $2^{\prime}$-phosphate, and 
$5^{\prime}$-phosphate substrates. The delineation of a tetranucleotide as a minimized RtcA substrate (and the ability to replace all but the $3^{\prime}$-terminal nucleotides by deoxys) will aid that effort.

\section{Is RtcA in a pathway with RtcB?}

The precipitating question for this study-can RNA cyclases convert a $2^{\prime}$-phosphate to a $2^{\prime}, 3^{\prime}$-cyclic phosphate?-has been answered in the affirmative for the cyclases RtcA and Rtcl from E. coli and humans, respectively. Thus, it is possible that RtcA serves a $2^{\prime}$-phosphate end healing function in an RNA repair pathway driven by RtcB. The rate of $2^{\prime}$-phosphate cyclization in vitro, though slow in comparison to $3^{\prime}$-phosphate cyclization, is not a deal-breaker, given the ability of RtcA to bind stably at an RNA 2'-phosphate end and to cyclize it in near-quantitative yield. Until we know more about the physiology of RtcA and RtcB (e.g., what stresses trigger their expression and what are their natural substrates for end-modification and repair?), we can only answer "maybe" to the issue of whether RtcA and RtcB are agents in a common biological pathway in E. coli. Nonetheless, for this scenario to be plausible, there must be some means of generating RNA 2'-phosphate ends in E. coli as substrates for RtcA. Bacterial ribotoxins are transesterifying endoribonucleases that yield 2',3'-cyclic phosphate RNA breaks. It is noteworthy that E. coli and many other bacteria encode an RNA $2^{\prime}, 3^{\prime}$-cyclic phosphoesterase that hydrolyzes cyclic phosphates to yield an RNA 2'-phosphate product (Kanai et al. 2009).

\section{Phylogenetics of $\boldsymbol{r t c} B \boldsymbol{A}$}

Many bacterial taxa encode RtcA and RtcB homologs, though it is usually not the case that they are genetically linked on the respective bacterial chromosomes as observed for the E. coli $r t c B A$ operon. RtcB and RtcA homologs are also found in many archaeal proteomes, but they are, to our inspection, never genetically clustered in an operon. Thus, the coregulation of RtcB and RtcA is the exception, not the rule. A list of 32 bacteria that do have an $r t c B A$ gene cluster adjacent to an $r t c R$ gene is compiled in Supplemental Table S1. These include diverse taxa from four different phyla, with a preponderance of examples from the several divisions of Proteobacteria. The $\diamond r t c R \cdot r t c B-r t c A \Rightarrow$ operon organization seen in E. coli is maintained in most of the other taxa, i.e., the $r t c R$ gene is upstream of $r t c B$ and divergently transcribed, and $r t c B$ precedes $r t c A$. There are notable exceptions. In Hahella chejuensis (a $\gamma$-proteobacterium), the gene arrangement is $r t c R-r t c A-r t c B \Rightarrow$, in which $r t c R$ is upstream of $r t c B$ but is transcribed in the same direction as $r t c B A$. In Pelobacter carbinolicus (a $\delta$-proteobacterium), the arrangement is $\diamond r t c R \bullet r t c A-r t c B \Rightarrow$, whereby the $r t c B A$ order is reversed, and the $r t c A$ ORF precedes $r t c B$. A conserved feature of the bacterial $\mathrm{rtcBA}$ operon is the presumptive coregulation of RtcB and RtcA production by the $\sigma^{54}$ coactivator RtcR. In E. coli, rtcBA expression is undetectable under normal growth conditions but can be induced by expressing a deleted version of RtcR that lacks an N-terminal auto-inhibitory module (Genschik et al. 1998). Identifying the stresses and molecular signals that activate RtcR and induce $r t c B A$ should provide instructive clues to the RNA transactions to which the repair enzymes are directed.

\section{Genetic association of bacterial Ro protein with $r t c B A$}

Many of the bacteria that have an $r t c R \cdot r t c B A$ cluster encode additional proteins within the putative operon, by interposing co-oriented ORFs, either upstream of $r t c B$ or between $r t c B$ and $r t c A$. The most prevalent variant of the operon encodes the RNA-binding protein Ro upstream of $r t c B$. The $\diamond r t c R \cdot r o-r t c B-r t c A \Rightarrow$ operon organization applies to 10 bacterial taxa (Fig. 1D). The $\sim 60-\mathrm{kDa}$ bacterial Ro protein, like its eukaryal Ro counterpart, is a toroidal ring composed of HEAT repeats plus a vWFA domain (Stein et al. 2005; Ramesh et al. 2007). Ro binds small RNAs, especially misfolded RNAs, and is thought to function in RNA quality control, including the recognition or processing of damaged RNAs (Chen et al. 2003). Single-strand RNA binds within the central cavity of the Ro ring; double-strand RNA binds on the outer surface of the ring (Stein et al. 2005; Fuchs et al. 2006). Wolin and colleagues have provided keen insights into the functions of bacterial Ro in Deinococcus radiodurans, where the Ro homolog (named Rsr) is induced during recovery from ultraviolet irradiation, associates with small noncoding RNAs, and contributes to the UV-resistance of Deinococcus (Chen et al. 2000). Their studies implicate Deinococcus Ro, together with exoribonucleases, in heatstress-induced maturation of ribosomal RNA and, together with polynucleotide phosphorylase, in starvation-induced rRNA decay (Chen et al. 2007; Wurtmann and Wolin 2010). Indeed, Deincococcus Ro and polynucleotide phosphorylase interact physically to form an RNA-scaffolded degradation complex (Chen et al. 2013).

The prototypal Ro-containing $\diamond r t c R \cdot r o-r t c B-r t c A \Rightarrow$ operon is found in Salmonella typhimurium, as illustrated in Fig. 1D. Consistent with the original E. coli findings, expression of the S. typhimurium Ro gene is undetectable under normal growth conditions but can be induced by production of a plasmid-encoded constitutively active $\mathrm{N}$-terminal truncation variant of S. typhimurium RtcR (Chen et al. 2013). The genomic "gap" between the Ro and RtcB ORFs encodes two small noncoding RNAs that associate with $S$. typhimurium Ro (Chen et al. 2013). This noncoding gap is a conserved feature of other Ro-containing bacterial $r t c B A$ operons (data not shown). We doubt it is mere coincidence that diverse bacterial taxa genetically cluster and coregulate an RNA quality control determinant (Ro) with two enzymes implicated in RNA end-modification (RtcA) and RNA repair (RtcB).

What is even more striking is that the two ORFs immediately downstream from the $S$. typhimurium $r t c A$ gene comprise a $\operatorname{dinJ}$ yafQ antitoxin:ribotoxin cassette (Fig. 1D). 
YafQ is a site-specific endoribonuclease (an "mRNA interferase") that associates with the ribosome, incises mRNA at inframe AAA lysine codons followed by a purine, and thereby arrests translation (Prysak et al. 2009; Armalyte et al. 2012). We can speculate that the effects of stress-induced ribotoxic damage caused by YafQ are modulated by coexpressing clustered genes that influence the recognition, decay, and/or repair of the broken RNAs.

\section{MATERIALS AND METHODS}

\section{RNA cyclase proteins}

Wild-type E. coli RtcA and mutant H309A were produced as N-terminal $\mathrm{His}_{10}$-tagged fusion proteins and purified from soluble bacterial extracts by sequential $\mathrm{Ni}$-agarose, anion-exchange, and gelfiltration chromatography steps as described (Chakravarty et al. 2011). Wild-type human Rtc1 and mutant H320A were purified from soluble bacterial extracts by sequential $\mathrm{Ni}$-agarose chromatography, ammonium sulfate precipitation, and gel-filtration chromatography steps as described (Tanaka and Shuman 2009). Protein concentrations were determined by using the Bio-Rad dye reagent with bovine serum albumin as the standard.

\section{RNA substrates}

The 20 -mer $\mathrm{RNA}_{3} \mathrm{p}$ substrate was prepared by enzymatic addition of $\left[5^{\prime}-{ }^{32} \mathrm{P}\right] \mathrm{pCp}$ to a $19-\mathrm{mer}$ RNA and then gel-purified (Das and Shuman 2013). The radiolabeled $\mathrm{RNA}_{3^{\prime}} \mathrm{p}$ strand was treated with E. coli RtcA and ATP to generate a $2^{\prime}, 3^{\prime}$-cyclic phosphate derivative, RNA > p. A $2^{\prime}$-phosphate-terminated derivative, $\mathrm{RNA}_{2^{\prime}} \mathrm{p}$, was produced by reacting $\mathrm{RNA}>\mathrm{p}$ with the cyclic phosphodiesterase domain of Arabidopsis thaliana tRNA ligase (Das and Shuman 2013). The conversion of $\mathrm{RNA}_{3^{\prime}} \mathrm{p}$ to RNA $>\mathrm{p}$ and then to $\mathrm{RNA}_{2^{\prime}} \mathrm{p}$ was verified by digestion of the RNAs with RNase T1 and analysis of the ${ }^{32} \mathrm{P}$-labeled terminal fragments by urea-PAGE. A $2^{\prime}, 3^{\prime}$-hydroxyl-terminated derivative, $\mathrm{RNA}_{\mathrm{OH}}$, was produced by reacting $\mathrm{RNA}_{3^{\prime}} \mathrm{p}$ with purified T4 polynucleotide kinase-phosphatase (Pnkp) for $30 \mathrm{~min}$ at $37^{\circ} \mathrm{C}$ in a reaction mixture $(100 \mu \mathrm{L})$ containing $100 \mathrm{mM}$ Tris acetate ( $\mathrm{pH}$ 6.0), $10 \mathrm{mM} \mathrm{MgCl}_{2}, 1 \mu \mathrm{MNA}_{3^{\prime}} \mathrm{p}$, and $50 \mu \mathrm{M}$ T4 Pnkp. The $\mathrm{RNA}_{\mathrm{OH}}$ product was recovered by phenolchloroform extraction and precipitation with ethanol.

\section{Cyclization assay}

Reaction mixtures containing $50 \mathrm{mM}$ Tris- $\mathrm{HCl}(\mathrm{pH} 7.4), 10 \mathrm{mM}$ $\mathrm{MgCl}_{2}, 2$ mM DTT, $20 \mathrm{nM}^{32} \mathrm{P}$-labeled $\mathrm{RNA}_{2^{\prime}} \mathrm{p}$ or $\mathrm{RNA}_{3^{\prime}} \mathrm{p}$ substrate, and wild-type or mutant RtcA were incubated at $37^{\circ} \mathrm{C}$. The reactions were quenched by adding either an equal volume of $100 \mathrm{mM}$ EDTA or $100 \mathrm{mM}$ EDTA plus 1\% SDS. The samples were extracted with phenol-chloroform to remove the SDS. The RNAs in the aqueous phase were digested with RNase T1 (1000 U; Fermentas) for 30 min at $37^{\circ} \mathrm{C}$. The samples were supplemented with 0.5 volume of $90 \%$ formamide, $0.01 \%$ bromophenol blue/xylene cyanol, $50 \mathrm{mM}$ EDTA, and then analyzed by electrophoresis (at $50 \mathrm{~W}$ constant power) through a $40-\mathrm{cm} 20 \%$ polyacrylamide gel containing $8 \mathrm{M}$ urea in $45 \mathrm{mM}$ Tris borate, $1.2 \mathrm{mM}$ EDTA. The ${ }^{32} \mathrm{P}$-labeled tetranucleotides HOCUUpCp and ${ }_{\mathrm{HO}} \mathrm{CUUpC}>\mathrm{p}$ were visualized by autoradiography of the gel and, where specified, quantified by scanning the gel with a Fuji Film BAS-2500 imager.

\section{Rapid kinetic analysis of $\mathbf{3}^{\prime}$-phosphate cyclization}

A Kintek RQF3 rapid chemical quench apparatus was used to assay the reaction of $\mathrm{RNA}_{3^{\prime}} \mathrm{p}$ with a 10 -fold molar excess of RtcA at $22^{\circ} \mathrm{C}$ in the absence of added ATP and $\mathrm{Mg}^{2+}$, in the range of $2 \mathrm{msec}-$ to 100 msec-reaction times. The reaction mixtures $(40 \mu \mathrm{L})$ contained $50 \mathrm{mM}$ Tris-HCl (pH 7.4), $2 \mathrm{mM}$ DTT, $20 \mathrm{nM}{ }^{32}$ P-labeled $\mathrm{RNA}_{3^{\prime}} \mathrm{p}$, and $200 \mathrm{nM}$ RtcA. The rapid kinetic measurements were initiated by mixing two solutions $(20 \mu \mathrm{L}$ each). One solution contained $50 \mathrm{mM}$ Tris- $\mathrm{HCl}$ ( $\mathrm{pH} 7.4$ ), 2 mM DTT, and $40 \mathrm{nM}{ }^{32} \mathrm{P}-\mathrm{la}-$ beled $\mathrm{RNA}_{3^{\prime}} \mathrm{p}$. The other solution contained $50 \mathrm{mM}$ Tris- $\mathrm{HCl}$ ( $\mathrm{pH} 7.4), 2 \mathrm{mM}$ DTT, and $400 \mathrm{nM}$ RtcA. The reactions were quenched by rapid mixing with $1 \%$ SDS, $100 \mathrm{mM}$ EDTA to a final volume of $150 \mu \mathrm{L}$. The mixtures were extracted with phenol-chloroform. The aqueous phase was removed and then digested with RNase T1. Aliquots of the samples were mixed with an equal volume of $90 \%$ formamide, $50 \mathrm{mM}$ EDTA and analyzed by electrophoresis through a $20 \%$ polyacrylamide gel containing $7 \mathrm{M}$ urea in $45 \mathrm{mM}$ Tris borate, $1.2 \mathrm{mM}$ EDTA. The ${ }^{32} \mathrm{P}$-labeled tetranucleotides ${ }_{\mathrm{HO}} \mathrm{CUUpC}>\mathrm{p}$ and ${ }_{\mathrm{HO}} \mathrm{CUUPC}_{3^{\prime}} \mathrm{p}$ were visualized by autoradiography and quantified by scanning the gel.

\section{RNA binding assay}

Reaction mixtures containing $50 \mathrm{mM}$ Tris- $\mathrm{HCl}$ (pH 7.4), $10 \mathrm{mM}$ $\mathrm{MgCl}_{2}, 2 \mathrm{mM}$ DTT, $20 \mathrm{nM}{ }^{32} \mathrm{P}$-labeled $\mathrm{RNA}_{2^{\prime}} \mathrm{p}$ or $\mathrm{RNA}_{3^{\prime}} \mathrm{p}$ or $\mathrm{RNA}_{\mathrm{OH}}$ substrate, and RtcA-H309A were incubated for $20 \mathrm{~min}$ at $37^{\circ} \mathrm{C}$. The mixtures were placed on ice and adjusted to $10 \%$ glycerol, $0.04 \%$ Triton-X 100 before analyzing them by electrophoresis (at $100 \mathrm{~V}$ constant voltage) through a $15-\mathrm{cm} 10 \%$ polyacrylamide gel containing $23 \mathrm{mM}$ Tris borate, $0.6 \mathrm{mM}$ EDTA. The free radiolabeled

${ }^{32} \mathrm{P}$-labeled RNAs and the RtcA $\bullet$ RNA complexes were visualized by autoradiography and, where specified, quantified by scanning the gel.

\section{SUPPLEMENTAL MATERIAL}

Supplemental material is available for this article.

\section{ACKNOWLEDGMENTS}

We thank Anupam Chakravarty and Barbara Remus for advice and assistance. This research was supported by NIH grant GM46330. S.S. is an American Cancer Society Research Professor.

Received May 2, 2013; accepted June 20, 2013.

\section{REFERENCES}

Armalyte J, Jurenaite M, Beinoraviciute G, Teiserskas J, Suziedelience E. 2012. Characterization of Escherichia coli dinJ-yafQ toxin-antitoxin system using insights from mutagenesis data. J Bacteriol 194: 1523-1532.

Billy E, Hess D, Hofsteenge J, Filipowicz W. 1999. Characterization of the adenylation site in the RNA $3^{\prime}$-terminal phosphate cyclase from Escherichia coli. J Biol Chem 274: 34955-34960. 
Chakravarty AK, Shuman S. 2011. RNA 3'-phosphate cyclase (RtcA) catalyzes ligase-like adenylylation of DNA and RNA $5^{\prime}$-monophosphate ends. J Biol Chem 286: 4117-4122.

Chakravarty AK, Shuman S. 2012. The sequential 2',3' cyclic phosphodiesterase and $3^{\prime}$-phosphate $/ 5^{\prime}-\mathrm{OH}$ ligation steps of the RtcB RNA splicing pathway are GTP-dependent. Nucleic Acids Res 40: 8558-8567.

Chakravarty AK, Smith P, Shuman S. 2011. Structures of RNA 3'-phosphate cyclase bound to ATP reveal the mechanism of nucleotidyl transfer and metal-assisted catalysis. Proc Natl Acad Sci 108: 21034-21039.

Chakravarty AK, Subbotin R, Chait BT, Shuman S. 2012. RNA ligase RtcB splices $3^{\prime}$-phosphate and $5^{\prime}-\mathrm{OH}$ ends via covalent RtcB-(histidinyl)-GMP and polynucleotide- $\left(3^{\prime}\right) \mathrm{pp}\left(5^{\prime}\right) \mathrm{G}$ intermediates. Proc Natl Acad Sci 109: 6072-6077.

Chen X, Quinn AM, Wolin SL. 2000. Ro ribonucleoproteins contribute to the resistance of Deinococcus radiodurans to ultraviolet irradiation. Genes Dev 14: 777-782.

Chen X, Smith JD, Shi H, Yang DD, Flavell RA, Wolin SL. 2003. The Ro autoantigen binds misfolded U2 small nuclear RNAs and assists mammalian cell survival after UV irradiation. Curr Biol 13: 2206-2211.

Chen X, Würtmann EJ, Van Batavia J, Zybailov B, Washburn MP, Wolin SL. 2007. An ortholog of the Ro autoantigen functions in 23S rRNA maturation in D. radiodurans. Genes Dev 21: 1328-1339.

Chen X, Taylor DW, Fowler CC, Galan JE, Wang HW, Wolin SL. 2013. An RNA degradation machine sculpted by Ro autoantigen and noncoding RNA. Cell 153: 166-177.

Das U, Shuman S. 2013. Mechanism of RNA 2',3'-cyclic phosphate endhealing by T4 polynucleotide kinase-phosphatase. Nucleic Acids Res 41: 355-365.

Englert M, Sheppard K, Aslanian A, Yates JR, Söll D. 2011. Archaeal 3'phosphate RNA splicing ligase characterization identified the missing component in tRNA maturation. Proc Natl Acad Sci 108: $1290-1295$.

Englert M, Xia S, Okada C, Nakamura A, Tanavde V, Yao M, Eom SH, Koningsberg WH, Söll D, Wang J. 2012. Structural and mechanistic insights into guanylylation of RNA-splicing ligase RtcB joining RNA between $3^{\prime}$-terminal phosphate and 5'-OH. Proc Natl Acad Sci 109: 15235-15240.

Filipowicz W, Strugala K, Konarska M, Shatkin AJ. 1985. Cyclization of RNA $3^{\prime}$-terminal phosphate by cyclase from HeLa cells proceeds via formation of $\mathrm{N}\left(3^{\prime}\right) \mathrm{pp}\left(5^{\prime}\right)$ A activated intermediate. Proc Natl Acad Sci 82: $1316-1320$.

Fuchs G, Stein AJ, Fu C, Reinisch KM, Wolin SL. 2006. Structural and biochemical basis for misfolded RNA recognition by the Ro autoantigen. Nature Struct Mol Biol 13: 1002-1009.

Genschik P, Billy E, Swianiewicz M, Filipowicz W. 1997. The human RNA 3'-terminal phosphate cyclase is a member of a new family of proteins conserved in Eukarya, Bacteria and Archaea. EMBO J 16: $2955-2967$.
Genschik P, Drabikowski K, Filipowicz W. 1998. Characterization of the Escherichia coli RNA 3'-terminal phosphate cyclase and its 654 -regulated operon. J Biol Chem 273: 25516-25526.

Kanai A, Sato A, Fukuda Y, Okada K, Matsuda T, Sakamoto T, Muto Y, Yokoyama S, Kawai G, Tomita M. 2009. Characterization of a heat-stable enzyme possessing GTP-dependent RNA ligase activity from a hyperthermophilic archaeon, Pyrococcus furiosus. RNA 15: 420-431.

Popow J, Englert M, Weitzer S, Schleiffer A, Mierzwa B, Mechtler K, Trowitzsch S, Will CL, Lürhmann R, Söll D, et al. 2011. HSPC117 is the essential subunit of a human tRNA splicing ligase complex. Science 331: 760-764.

Popow J, Schleiffer A, Martinez J. 2012. Diversity and roles of (t)RNA ligases. Cell Mol Life Sci 69: 2657-2670.

Prysak MH, Mozdzierz CJ, Cook AM, Zhu L, Zhang Y, Inouye M, Woychik NA. 2009. Bacterial toxin YafQ is an endoribonuclease that associates with the ribosome and blocks translation elongation through sequence-specific and frame-dependent mRNA cleavage. Mol Microbiol 71: 1071-1087.

Ramesh A, Savva CG, Holzenburg A, Sacchettini JC. 2007. Crystal structure of Rsr, an ortholog of the antigenic Ro protein, links conformational flexibility to RNA binding activity. J Biol Chem 282: 1496014967.

Reinberg D, Arenas J, Hurwitz J. 1985. The enzymatic conversion of 3'-phosphate terminated RNA chains to $2^{\prime}, 3^{\prime}$-cyclic phosphate derivatives. J Biol Chem 260: 6088-6097.

Remus BS, Shuman S. 2013. A kinetic framework for tRNA ligase and enforcement of a $2^{\prime}$-phosphate requirement for ligation highlights the design logic of an RNA repair machine. RNA 19: 659-669.

Stein AJ, Fuchs G, Fu C, Wolin SL, Reinisch KM. 2005. Structural insights into RNA quality control: The Ro autoantigen binds misfolded RNAs via its central cavity. Cell 121: 529-539.

Tanaka N, Shuman S. 2009. Structure-activity relationships in human RNA 3'-phosphate cyclase. RNA 15: 1865-1874.

Tanaka N, Shuman S. 2011. RtcB is the RNA ligase component of an Escherichia coli RNA repair operon. J Biol Chem 286: 77277731.

Tanaka N, Smith P, Shuman S. 2010. Structure of the RNA 3'-phosphate cyclase-adenylate intermediate illuminates nucleotide specificity and covalent nucleotidyl transfer. Structure 18: 449-457.

Tanaka N, Meineke B, Shuman S. 2011a. RtcB, a novel RNA ligase, can catalyze tRNA splicing and HAC1 mRNA splicing in vivo. J Biol Chem 286: 30253-30257.

Tanaka N, Chakravarty AK, Maughan B, Shuman S. 2011b. Novel mechanism of RNA repair by RtcB via sequential $2^{\prime}, 3^{\prime}$-cyclic phosphodiesterase and $3^{\prime}$-phosphate/ $5^{\prime}$-hydroxyl ligation reactions. $J$ Biol Chem 286: 43134-43143.

Wurtmann EJ, Wolin SL. 2010. A role for a bacterial ortholog of the Ro autoantigen in starvation-induced rRNA degradation. Proc Natl Acad Sci 107: 4022-4027. 

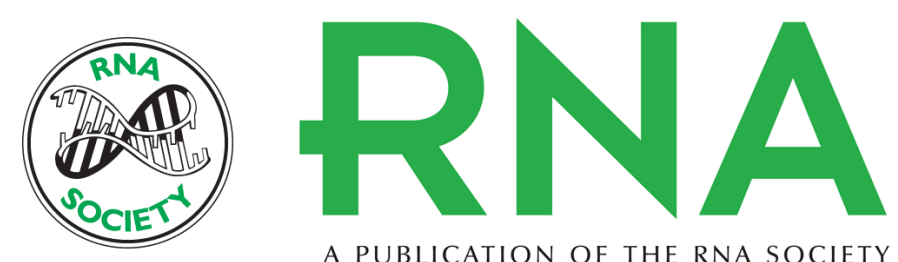

A PUBLICATION OF THE RNA SOCIETY

\title{
2'-Phosphate cyclase activity of RtcA: a potential rationale for the operon organization of RtcA with an RNA repair ligase RtcB in Escherichia coli and other bacterial taxa
}

\author{
Ushati Das and Stewart Shuman
}

RNA 2013 19: 1355-1362 originally published online August 14, 2013

Access the most recent version at doi:10.1261/rna.039917.113

\section{Supplemental} Material

References

Creative Commons License

Email Alerting Service
http://rnajournal.cshlp.org/content/suppl/2013/08/05/rna.039917.113.DC1

This article cites 31 articles, 22 of which can be accessed free at: http://rnajournal.cshlp.org/content/19/10/1355.full.html\#ref-list-1

This article is distributed exclusively by the RNA Society for the first 12 months after the full-issue publication date (see http://rnajournal.cshlp.org/site/misc/terms.xhtml). After 12 months, it is available under a Creative Commons License (Attribution-NonCommercial 3.0 Unported), as described at http://creativecommons.org/licenses/by-nc/3.0/.

Receive free email alerts when new articles cite this article - sign up in the box at the top right corner of the article or click here.

To subscribe to $R N A$ go to:

http://rnajournal.cshlp.org/subscriptions 